\title{
Does Audit Quality in Libya Meet the International Standards Levels?
}

\author{
Nedal Sawan ${ }^{1} \&$ Abdulaziz Alzeban ${ }^{2}$ \\ ${ }^{1}$ Liverpool Business School, UK \\ ${ }^{2}$ King Abdulaziz University, Saudi Arabia \\ Correspondence: Nedal Sawan, Liverpool Business School, UK. E-mail: ne2000dal@hotmail.com
}

Received: February 19, 2015

Accepted: April 7, 2015

Online Published: May 25, 2015

doi:10.5539/ijbm.v10n6p155

URL: http://dx.doi.org/10.5539/ijbm.v10n6p155

\begin{abstract}
This study provide empirical evidence of the current situation and measure the perceptions of the level of audit quality in Libya by focusing on oil companies. It aims to examine the extent to which Libyan Accountants and Auditors Association (LAAA) and audit firms and play an essential role in enhancing the quality of audit and developing the audit profession. A questionnaire and interviews were used to collect data from audit firm that works in Libya and Libyan oil companies. The study finds that there is a lack of professionalism among auditors in Libya is pervasive and that weaknesses in the current regulatory framework are detrimental and have led to the ineffectiveness of the LAAA. In addition, the ignorance of audit firms in Libya in respect of new services, and the inability of Libya's education system to produce competent graduates, all contribute to the low level of audit quality that the profession.
\end{abstract}

Keywords: Audit quality, Libya, accounting profession, developing countries, audit, LAAA.

\section{Literature Review}

Studies of Libyan Accountants and Auditors Association and audit quality have been relatively few in number, if any, in Libya. In this context, this study makes contribution to an under researched topic area within the oil sector as there is a need for further and more research. Following sections shed the light on the related literature to obtain an understanding of the topic under consideration, as the pace and scale of political change in Libya over the last few months is so drastic, therefore this study's contribution to the audit debate seems to be all the more useful.

\subsection{Auditor Attributes and Audit Quality}

The literature and standards governing audit conduct do highlight a number of factors that can promote and strengthen audit quality, all of which can be categorised as ability and professional conduct (Catanach \& Walker, 1999). Auditor attributes covering such characteristics as ability to scrutinise, technical competence, knowledge, experience, industry specialisation, technological proficiency (Catanach \& Walker, 1999), and professional scepticism (IAASB, 2004b), are seen to be pre-requisites.

With respect to industry specialisation, it has been confirmed by several studies (Balsam et al. 2003; Owhoso et al. 2002) that auditor's knowledge of the industry provides the auditor with the capacity to be more effective and to report lower discretionary accruals than those of non-specialist auditors, and according to other studies (Hogan \& Jeter, 1999; Solomon et al., 1999) to promote high quality. It is also found (Lys \& Watts, 1994) that technological skills are a positive attribute of auditors since this allows for the provision of more structured audit activities that improve audit quality.

Accordingly, ISA 240 states that auditors should demonstrate a questioning mind, a critical valuation of audit evidence, and proper planning and execution of an audit (IAASB, 2004a). It also places a duty on auditors to identify any fraudulent activities (IAASB, 2004b). Clearly, this regulation is aimed at developing professional scepticism in the interests of a rigorous audit process.

Likewise, the AICPA (1991, pp. 4-12) stipulates the need for auditors to display their judgement, due professional care, objectivity, independence, and integrity (Catanach \& Walker, 1999; Porter et al. 2003), and the APB (2004) focuses on the requirement for integrity, objectivity, and independence as ethical standards to be upheld in the auditing process. The IFAC (2005) emphasises independence as the key attribute from which integrity, objectivity, and professional scepticism follow. All of these characteristics signal the absolute 
requirement for the absence of any personal bias whatsoever within auditors (Porter et al., 2003).

\subsection{The Status of Libyan Auditing the Accounting Profession}

A comprehensive analysis of the accounting profession in a particular country can only be made if that country's cultural characteristics are considered and appreciated as having an influence upon how the profession develops and is maintained. In cultural terms, Libya complies with the Arab country classification as identified by Hofstede (1984), and hence within the Libyan society, there are high levels of power distance and uncertainty avoidance demonstrated. This carries through into the accounting profession, which essentially is not well developed (Selway, 2000).

However, despite several early efforts to reinforce and enhance the Libyan accounting education, the regulatory body in Libya-the Libyan Accountants and Auditors Association (LAAA) - is relatively young, being in existence for only 35 years, having been established by Law No. 116 in 1973. The responsibilities of the LAAA are essentially to oversee and supervise the accounting profession, whilst at the same time ensuring its development and the continuing professional development of its members through the provision of national and international conferences and seminars (Saleh, 2001). Since the establishment of the LAAA, more formalities have been introduced in the profession, but in practice, very little has been achieved by the body in terms of building and implementing a theoretical base for accounting as a profession, and a much-needed Code of Ethics that would improve professional practice, is sadly missing (Bakar \& Russell, 2003).

Consequently, it can be argued that the LAAA is not fit for purpose as it has not succeeded in fulfilling its obligations as a regulatory body and is not operating in the public interest. Moreover, there have been few efforts by the LAAA to promote continuing education and staff training amongst accountants as a means of improving the status of the profession (Shareia, 1994). Hence, the Libyan accounting profession has poor status.

\subsection{Accounting Professional Body in Libya}

It was not until 1973 that auditing regulations were introduced in Libya. Prior to that time, there was no requirement for business enterprises to have their financial statements scrutinised and certified by an independent auditor. Instead, it was only necessary for such documents to be agreed by the legal authority of the taxpayer (the business) and this person could simply be a chartered accountant (Law No. 64 of 1973). On 20th December 1973, however, the Libyan government finally enacted Law No. 116 of 1973, which established the LAAA as a body which would develop the auditing profession in Libya. The LAAA was given the following objectives:

- To structure, improve the condition and quality of the auditing profession, raise the professional standards of auditors and accountants, academically, culturally and socially.

- Organising conferences, seminars, to be updated with new events, issue periodicals, and provide lectures.

- To establish assistance and pension funds for its members.

- Enhancing the cooperation between the LAAA members and providing protection to their rights.

- Setting regulation for those who violate the profession and ethics, and take required action as well.

- To register as a Chartered Accountant in Libya.

Registering as a chartered accountant with the LAAA is mandatory in order to perform any kind of auditing activity (Law No. 116, article 32). This regulation is intended to guarantee that all audits are performed by people who have the appropriate qualifications, and who are at the same time, properly supervised. LAAA registration in itself can only be obtained if the following conditions are met.

Citizenship: applicants for membership of the LAAA must be Libyan citizens.

Residence: applicants should reside in Libya.

Educational experience: applicants should have an accounting degree from the Faculty of Economics and Commerce of a Libyan university, or any other recognised university or higher institute. For applicants to be registered in the accountants' register they should at least possess five years' of experience in accounting in independent public accountant after graduation. Experience requirement can be waived for those who possess a degree higher than bachelor's, in addition to four or more years training. Those who are already practising the profession who do not have a University or Higher Institute degree should be registered as working auditors on condition that they may only be considered as accountants or auditors' assistants.

The Executive Memorandum of Law No.116 of 1973 explains in Article 24 of the law which relates to the required qualifications and experience for registration with the LAAA, as a chartered account which are: 
Doctoral degree in accounting, auditing, taxation or costing from any recognised Arab or international university. Membership of the Institute of Chartered Accountants in England and Wales.

Membership of the American Accountants Association.

Any certificate equivalent to those mentioned above obtained from any recognised university or institute specialising in accounting or auditing that required four years or more for graduation.

Obtaining Bachelor's degree in accounting and experience of five years' in accounting in an independent public accountant or doing one of the following jobs:

- Manager or head of an accounting or auditing department in the Treasury Ministry.

- Accountant or auditor working for the Accounting Council.

- Accountant or auditor working for the Taxation Authority.

- Manager or head of an Accounting department in a public bank or enterprise.

- Teacher of accounting or auditing in any public university or institute.

- Any other jobs equivalent to the jobs mentioned above approved by the LAAA.

Three years' experience of work in a capacity mentioned above, in addition to the following:

- To be a member of the Chartered Institute of Management Accountants in England or any equivalent certificate.

- To be a member of the Association of Chartered Certified Accountants in England or any equivalent certificate.

- To be a member of the Taxation Association in England or any equivalent certificate.

\section{The Libyan Oil Economy}

Since Libya producing high quality and low sulphur oil and gas, and also because of its strategic position in respect of the Mediterranean and European markets, Libya's economy is almost totally reliant on oil (Table 1). Indeed, it is considered to be as one of the largest oil producer (World Markets Research Centre, 2002), with known oil reserves amounting to at least $30 \mathrm{bn}$ barrels, and possibly rising to $50 \mathrm{bn}$, given the potential for future exploration and discovery. One key reason for Libya's low costs of oil production is that the reserves lie close to the surface. The dominance of the industry is shown in the period 2000-2005, when the percentage of oil exports to total exports reached above $97 \%$.

According to the World Markets Research Centre (2002), Liquefied Natural Gas will increasingly become a key source of foreign exchange revenue, and the country is eager to exploit its potential. Exports to Italy and other central European markets started in 2003, as also did a joint Libyan/Italian venture to develop both onshore and offshore reserves.

Table 1. Libyan exports in the period 1996-2005

\begin{tabular}{lcc}
\hline Year & Oil exports\% & Non-Oil exports\% \\
\hline $\mathbf{1 9 9 6}$ & 81.3 & $\mathbf{1 8 . 7}$ \\
$\mathbf{1 9 9 7}$ & 92.1 & $\mathbf{7 . 9}$ \\
$\mathbf{1 9 9 8}$ & 92.9 & $\mathbf{7 . 1}$ \\
$\mathbf{1 9 9 9}$ & 93.5 & $\mathbf{6 . 5}$ \\
$\mathbf{2 0 0 0}$ & 96.3 & $\mathbf{3 . 7}$ \\
$\mathbf{2 0 0 1}$ & 95.3 & $\mathbf{4 . 7}$ \\
$\mathbf{2 0 0 2}$ & 97.8 & $\mathbf{2 . 2}$ \\
$\mathbf{2 0 0 3}$ & 97.2 & $\mathbf{2 . 8}$ \\
$\mathbf{2 0 0 4}$ & 96.3 & $\mathbf{3 . 7}$ \\
$\mathbf{2 0 0 5}$ & $\mathbf{9 8 . 2}$ & $\mathbf{1 . 8}$ \\
\hline
\end{tabular}

Source: Central Bank of Libya (2006).

This joint venture includes the finalisation of the Western Libya Gas Project, the subsequent construction of a gas processing site, and the proposed construction of a 1,200 km pipeline from the coast in the north of Libya to Sicily. As a means to improve production, the government also wants to upgrade its main plant, with the aim of raising production capability to one billion cubic metres a year, from the present $4.5 \mathrm{~m}$. 


\subsection{Methods and the Sampling Unit}

The study was operationalised using an approach involving the use of questionnaires and semi-structured interviews as a means of securing data from a comprehensive sample Libyan auditing professionals. Questionnaires were designed to gather the perceptions of oil firms, representing the demand side, and audit companies working in Libya, representing supply side. Within the sample of oil firms, three categories of respondent were targeted, these being: accounts managers, internal auditors, and financial managers, since these individuals were indicated in the literature as being those with whom the external auditor is usually in more contact. In respect of the audit firms, employees at all levels were involved, in order to canvass opinion from auditors, managing partners, and supervisors of audit.

The oil companies were chosen as the sample to represent the demand side because they have traditionally been characterised by a high level of organisation, and the vast majority of them recruit staff with degrees from the US or UK. Oil firms carry out a large variety of activities and their accounting systems are complex in order to service these activities, thereby making these companies attractive to qualified accountants from different backgrounds. Consequently they provided the researcher with the ability to reach a large heterogeneous community of accountants, and were believed to be capable of delivering the data required.

As a means of triangulating the data secured from the questionnaire, semi-structured interviews were also undertaken with a similar sample of participants (oil company personnel-in the main accounts managers, internal auditors, and financial managers; and audit firm professionals- auditors, managing partners, and supervisors of audit). This interview exercise also included regulators from the LAAA since the responses to the questionnaire left some areas requiring clarification, and it was also considered that an input from this dimension would be an additional aid to triangulation. In all, ten interviews were performed with oil company personnel (three accounts managers, three internal auditor, and four financial manager), and thirteen with audit form personnel (three auditors, four managing partners, six supervisor of audit). Two were held with LAAA regulators. The interview data was explored using the technique of Content Analysis.

The questionnaire was constructed to cover three main areas of interest. The first gathered opinions from the respondents (internal, external, and taxation auditors) concerning the influences of academic qualifications and auditors' professional on the quality of evidence they produce. The second requested opinions concerning the impact of evidence consistency on audit evidence, and the last area of interest was the influence of the amount of evidence on evidence quality. Opinions were measured using a 5-point Likert scale (as recommended by Saunders et al., 2007) ranging as 1 is equal to strongly weaken evidence to 5 is equal to strongly improve evidence.

147 questionnaires survey were distributed to oil firms in a total of 147, as follows: 45 accounts managers, 52 internal auditors, and 50 financial managers. A further 300 questionnaires were distributed to audit companies, in equal numbers of 100 each to auditors, managing partners, and supervisors of audit. These individuals represent the agent of the principal, and consequently their performance is measured by a monitoring mechanism. The respondents from auditors, managing partners, supervisors of audit comprise the interest of the main subjects as they provide certification and/or measurement of the credibility of information to the stakeholders (Humphrey, 1997). It is observed by Hasan (2000) that audit quality is assessed by audit companies and their customers in different ways. Hence, it was necessary to secure opinions in this respect from both the demand and the supply side samples.

In an attempt to minimise problems of non-response, the questionnaire was comprised of closed questions in the main since these are easy for respondents to answer. A pilot study revealed that the questionnaire wording was clear and straightforward, and that the layout of the instrument was logical and of an appropriate length. The majority of the questionnaires were personally delivered and collected personally (56 auditors, 52, managing partners, 52 supervisors of audit - 52, 35 accounts managers, 45 internal auditors, 47 financial managers, while the rest were distributed personally and collected personally or returned by mail. Consequently, negative issues concerning anonymity and the use of mail services were avoided as far as possible. The survey comprised all the oil companies listed with the NOC, and 100 audit companies.

Table 2 reveals that the response rate was favourable at $64 \%$. A figure of $60 \%$ is considered as exemplary by Remenyi et al. (2002). Respectively, the response rates were: internal auditors $-86.5 \%$, financial managers $-94 \%$, accounts managers $-77.7 \%$, managing partners $-52 \%$, and audit supervisors $-52 \%$. Because of logistical problems, including poor communication and the ineffective postal system, the researcher was not able to chase up non-returns outside of Tripoli. 
Table 2. Response rate

\begin{tabular}{llll}
\hline Group & Distributed questionnaires & Useable questionnaires & Response rate \\
\hline Auditor & 100 & 56 & $56 \%$ \\
Accounts Manager & 45 & 35 & $77.7 \%$ \\
Financial Manager & 50 & 47 & $94 \%$ \\
Managing Partner & 100 & 52 & $52 \%$ \\
Internal Auditor & 52 & 45 & $86.5 \%$ \\
Supervisor of Audit & 100 & 52 & $52 \%$ \\
Total & 447 & 287 & 64 \\
\hline
\end{tabular}

\section{Results and Discussion}

\subsection{Quantitative Findings}

\subsubsection{The Current Perception of Audit Quality in Libya}

As shown in Table 3, an analysis of respondents by oil company and audit firm reveals that $68.5 \%$ of oil firms participants either strongly agreed or agreed with the item that: current level of audit quality in Libya is insufficient (mean values of 3.87). In respect of audit firm respondents, this percentage was $56.3 \%$ (a mean value of 3.46). This could be due to several reasons: firstly, the perceived lack of professionalism among auditors in Libya, since $51.9 \%$ and $43.8 \%$ of respondents (oil companies and audit firms respectively) either strongly agreed or agreed with the item that: The lack of the professionalism of auditors in Libya causes the low level of audit quality (mean values of 3.31 and 3.21). Secondly, the LAAA is seen to have contributed nothing as indicated by the fact that $66.1 \%$ and $64.4 \%$ of respondents from the oil firms and audit companies either strongly disagree or disagree with the item that: The LAAA plays an essential role in enhancing the quality auditing and developing audit profession (a mean value of 2.35 and 2.49). This finding is consistent with Mousa (2005) who suggested are the small size and limited authority of the LAAA.

Thirdly, respondents from both the oil companies and audit firms (59\% and 61.3\% respectively) believed that the Rules and regulations in Libyan are not comprehensive provisions that lack and cause low level audit quality (mean values of 3.55 and 3.61).

Overall perceptions of respondents from both groups can be seen as $66.9 \%$ and $59.4 \%$ in terms of either strongly disagree or agree with the item that Most oil companies in Libya prefer audit firms that are affiliated to foreign audit companies and audit quality depends on the status of the audit company e.g. local affiliated to a foreign audit firm (mean value of 4.00 and 3.46). An explanation of obtaining these results can be referred to: firstly, the international audit firms tend to exercise a higher level of professionalism to protect their reputations. Secondly, local auditing companies affiliated to a foreign audit company are larger in terms of size and, therefore, obtain more exposure from the type of clients they have audited. Additionally, they may be subject to more control from their foreign affiliated firms. 
Table 3. Distribution of evaluations of different items related to current perception of audit quality in Libya

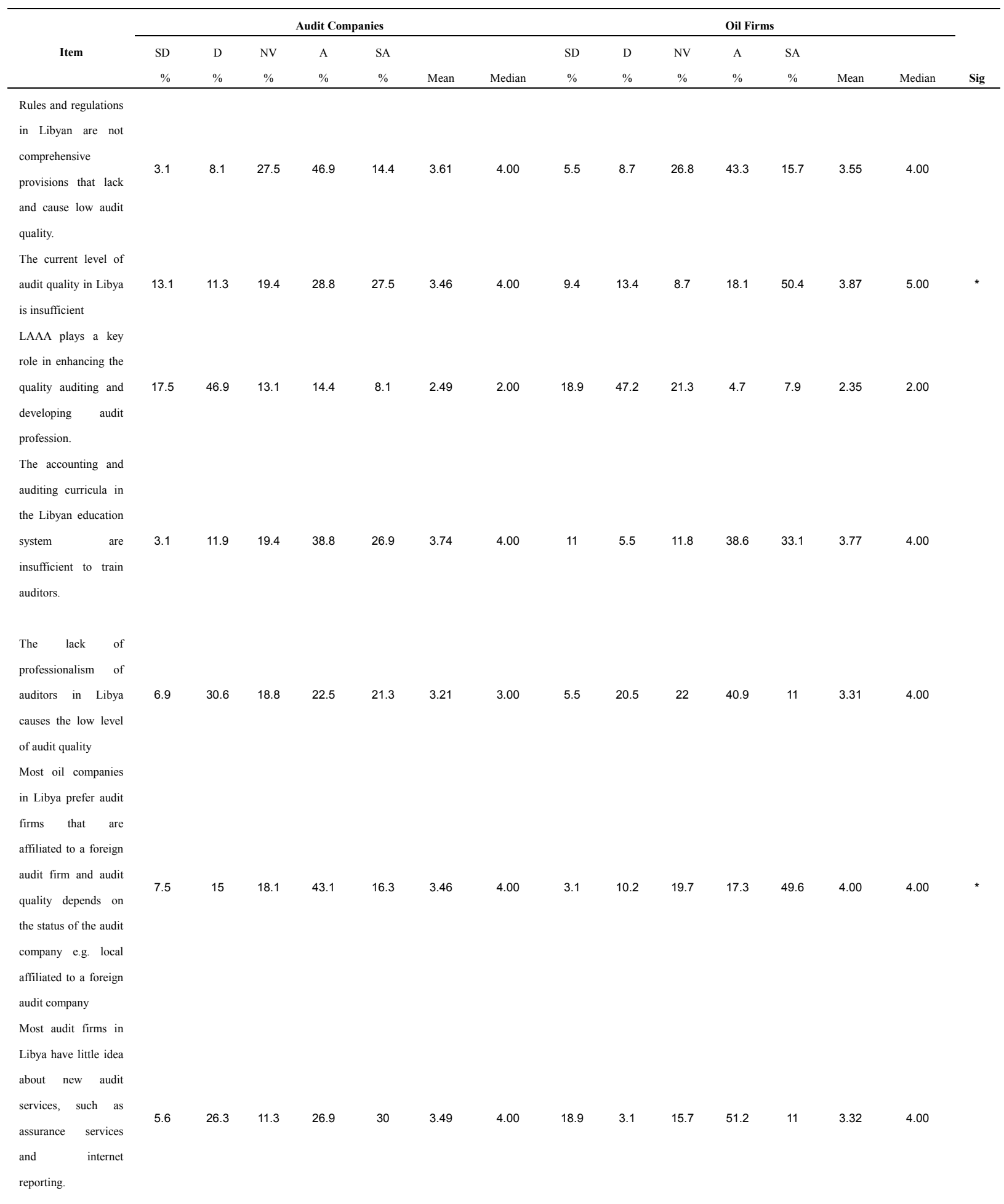

* Significant at the level of $5 \%$;* Significant at the level of $1 \%$.

Another interesting finding is that just over half of the respondents $(62.2 \%$ and $56.9 \%$ in oil companies and audit firms respectively) either strongly agree or agree with the item that Most audit firms in Libya have little idea about new services, such as assurance services and Internet reporting (mean values of 3.32 and 3.49), and 71.7\% and $65.7 \%$ either strongly agree or agree with the item that The accounting and auditing curricula in the Libyan education system are insufficient to train auditors (mean values of 3.77 and 3.74). This finding is consistent with 
those of Mautz and Sharaf (1961, p. 159) who state that "all auditors are first accountants, or at least trained as accountants, because one cannot effectively verify accounting data unless he has some knowledge of how they were gathered; summarized, and classified, and presented. He must know the procedures and practices of accounting and be familiar with its devices and techniques. Thus accounting provides a necessary background for the study of auditing."

From the above analysis, it is clear that responses from audit companies and oil firms are not homogeneous; therefore, an attempt is made to isolate the determinants of responses.

The results reveal that there are two significant differences at level of $1 \%$. It was found that although $68.5 \%$ of Oil Company and $56.3 \%$ of audit company participants agreed with the item that: current level quality audit in Libya is insufficient, the overall responses were significant at level of 1\% (Mann Whitney $U$ test). An explanation of this result might be attributed to that oil companies appear to be aware of insufficiencies and inadequacies in the Libyan auditing environment and are unhappy with the situation. This supports the findings in the descriptive analysis (see Table 3).

Moreover, both oil companies and audit firms show a level of agreement with the item that Most oil firms in Libya prefer audit companies that are affiliated to a foreign audit company and audit quality depends on the status of the audit company e.g. local affiliated to a foreign audit company was significantly higher at the $1 \%$ level of significance in respect of the oil firms participants (66.9\% either strongly agree or agree) than the audit firm respondents $(59.4 \%$ either strongly agree or agree). This mismatch in the responses of the two research populations is unsurprising, as companies engaging foreign audit firms are likely to support such a statement.

\subsubsection{The Current Perceptions of Audit Quality According to Position}

Table 4 indicates the overall perceptions of respondents from the staff of Audit Company and oil firm with a significant difference in the distribution of responses at $5 \%$ significance, and two significant differences at $1 \%$ as tested by of Kruskal-Wallis. Financial managers and accounts managers have a higher mean score of (4.00, and 4.04) and audit supervisors, auditors and managing partners had the lowest mean scores $(3.33 ; 3.38$ and 3.67$)$ for the statement Most oil companies in Libya prefer audit firms that are affiliated to foreign audit firms and audit quality depends on the status of the audit company e.g. local affiliated to a foreign audit company. Similarly, due to Foreign Investments Regulations in Libya Law No 116 which allows only Libyans to open audit offices, all foreign audit firms in the country, whether Arab, International or one of the Big Four, must be affiliated to a local audit firm. Therefore, not surprisingly, audit supervisors and managing partners, as Libyan owners would not support this statement, since it apparently favours foreign audit firms over local audit firms, taking into account that in a Libyan context, all other staff of audit firms are not usually Libyan nationals.

With regards to the statement of most audit firms in Libya have limited knowledge about new audit services, such as assurance services and internet reporting, the accounts managers had a significantly higher mean score of (4.14) and audit supervisors had a lower mean score (2.90). Again, this is a result that does not come as a surprise, since audit supervisors are not likely to support the statement, given that it criticises local audit firms. This finding may be interpreted in two ways: either the majority of audit clients in Libya are still audited using traditional methods, or the type of sample (oil companies) is ignorant about new services, such as assurance services and internet reporting. The literature is confirmed by this outcome, since scholars report that foreign audit firms perform more powerful and effective tests than local audit firms because of their experience and knowledge, and hence, produce higher audit quality (Dopuch \& Simunic, 1980).

Table 4 shows only one significant difference in the distribution of responses for the statement. The current level of the quality audit in Libya is insufficient at the level of 5\% significance. Financial managers and accounts managers have a significantly high mean score of (4.00 and 3.94) and auditors and audit supervisors had a lower mean score of (3.25 and 3.52). This result may reflect the situation that financial and accounts managers are unhappy with the level of audit quality than auditors and audit supervisors believe. 
Table 4. Distribution of different items related to current perception of audit quality according to position

\begin{tabular}{|c|c|c|c|c|c|c|c|c|c|c|c|c|c|}
\hline \multirow{3}{*}{ Item } & \multicolumn{6}{|c|}{ Audit Firm Staff } & \multicolumn{6}{|c|}{ Oil Company Staff } & \multirow{3}{*}{ Sig } \\
\hline & \multicolumn{2}{|c|}{ Managing Partner } & \multicolumn{2}{|c|}{ Audit Supervisor } & \multicolumn{2}{|c|}{ Auditor } & \multicolumn{2}{|c|}{ Internal Auditor } & \multicolumn{2}{|c|}{ Financial Manager } & \multicolumn{2}{|c|}{ Accounts Manager } & \\
\hline & Mean & Median & Mean & Median & Mean & Median & Mean & Median & Mean & Median & Mean & Median & \\
\hline $\begin{array}{l}\text { Rules and regulations in Libyan are } \\
\text { not comprehensive provisions that } \\
\text { lack and cause low audit quality. }\end{array}$ & 3.71 & 4.00 & 3.65 & 4.00 & 3.48 & 4.00 & 3.38 & 4.00 & 3.49 & 4.00 & 3.86 & 4.00 & \\
\hline $\begin{array}{l}\text { The current level of audit quality in } \\
\text { Libya is insufficient }\end{array}$ & 3.63 & 4.00 & 3.52 & 4.00 & 3.25 & 3.00 & 3.69 & 4.00 & 3.94 & 4.00 & 4.00 & 5.00 & $* *$ \\
\hline $\begin{array}{l}\text { LAAA plays a key role in enhancing } \\
\text { the quality auditing and developing } \\
\text { audit profession }\end{array}$ & 2.42 & 2.00 & 2.40 & 2.00 & 2.63 & 2.00 & 2.38 & 2.00 & 2.47 & 2.00 & 2.17 & 2.00 & \\
\hline $\begin{array}{l}\text { The accounting and auditing curricula } \\
\text { in the Libyan education system are } \\
\text { sufficient to train auditors. }\end{array}$ & 3.77 & 4.00 & 3.65 & 4.00 & 3.80 & 4.00 & 3.62 & 4.00 & 3.66 & 4.00 & 4.11 & 4.00 & \\
\hline $\begin{array}{l}\text { The lack of professionalism of } \\
\text { auditors in Libya causes the low level } \\
\text { of audit quality }\end{array}$ & 3.42 & 4.00 & 2.98 & 2.50 & 3.21 & 3.00 & 3.22 & 3.00 & 3.26 & 4.00 & 3.51 & 4.00 & \\
\hline $\begin{array}{l}\text { Most oil companies in Libya prefer } \\
\text { audit firms that are affiliated to } \\
\text { foreign audit firm and audit quality } \\
\text { depends on the status of the audit } \\
\text { company e.g. local affiliated to a } \\
\text { foreign audit company }\end{array}$ & 3.67 & 4.00 & 3.33 & 4.00 & 3.38 & 4.00 & 3.96 & 5.00 & 4.04 & 4.00 & 4.00 & 4.00 & * \\
\hline $\begin{array}{l}\text { Most audit firms in Libya have little } \\
\text { idea about new audit services. Such as } \\
\text { assurance services and internet } \\
\text { reporting. }\end{array}$ & 3.67 & 4.00 & 2.90 & 2.90 & 3.88 & 5.00 & 3.02 & 4.00 & 3.00 & 5.00 & 4.14 & 4.00 & * \\
\hline
\end{tabular}

* Significant at the level of 5\%; ** Significant at the level of $1 \%$.

\subsubsection{The Current Perceptions of Audit Quality According to the Type of Audit Firm}

Table 5 reveals the analysis of current perceptions of audit quality by type of Audit Company. It shows one significant difference at the level of 5\% between local audit companies, local companies affiliated to an Arab and/or International company, and local companies affiliated to one of the Big Four. The result was found significant at 5\%. The level of agreement with the item most oil companies in Libya prefer audit firms that are affiliated to foreign audit firms and audit quality depends on the status of audit company e.g. local affiliated to a foreign audit company was significantly lower from local, Arab and international audit company (non-Big Four audit firm) participants than from Big Four audit company participants. The result may be due to the fact that the Big Four are generally perceived as more professional than the non-Big Four in the auditing environment and have their own quality standards. This is not surprising, since this statement describes foreign audit firms more favourably than local audit firms. 
Table 5. Distribution of different items related to the current perceptions of audit quality according to the type of audit compnay

\begin{tabular}{|c|c|c|c|c|c|c|c|}
\hline \multirow[t]{2}{*}{ Statement } & \multicolumn{2}{|c|}{ Local Audit company } & \multicolumn{2}{|c|}{$\begin{array}{l}\text { International } \\
\text { Company }\end{array}$} & Audit & Big Four & \multirow[t]{2}{*}{ Sig } \\
\hline & Mean & Median & Mean & Median & Mean & Median & \\
\hline Rules and regulations in Libyan are not comprehensive provisions that lack and cause low audit quality. & 3.63 & 4.00 & 3.47 & 4.00 & 3.86 & 4.00 & \\
\hline The current level of audit quality in Libya is insufficient & 3.41 & 4.00 & 3.58 & 4.00 & 3.48 & 3.00 & \\
\hline LAAA plays a key role in enhancing the audit quality and developing audit profession & 2.45 & 200 & 2.51 & 2.00 & 2.62 & 2.00 & \\
\hline The accounting and auditing curricula in the Libyan education system are insufficient to train auditors. & 3.68 & 4.00 & 3.74 & 4.00 & 4.05 & 4.00 & \\
\hline The lack of professionalism of auditors in Libya causes the low level of quality auditing & 3.32 & 3.00 & 3.05 & 3.00 & 3.00 & 3.00 & \\
\hline $\begin{array}{l}\text { Most oil companies in Libya prefer audit firms that are affiliated to foreign audit firms and audit quality } \\
\text { depends on the status of the audit company e.g. local affiliated to a foreign audit company }\end{array}$ & 3.21 & 3.00 & 3.45 & 4.00 & 4.00 & 4.00 & ** \\
\hline $\begin{array}{l}\text { Most audit firms in Libya have little idea about new audit services, such as assurance services and internet } \\
\text { reporting. }\end{array}$ & 3.47 & 4.00 & 3.37 & 4.00 & 3.86 & 4.00 & \\
\hline
\end{tabular}

* Significant at the level of $5 \%$; * Significant at the level of $1 \%$

\subsection{Qualitative Findings}

\subsubsection{The Current Perceptions of Audit Quality in Libya}

DeAngelo (1981) pointed out that quality auditing depends on the capability of the auditor to perform a comprehensive examination of the accounts and detect possible irregularities or errors (technical competency), and his/her readiness to give an objective opinion (his/her independence). The concerns of audit quality are relevant for economies in transition, as is the case for Libya. With the movement of many global accounting companies into Libya, and the development of local audit companies, it is particularly interesting, and relevant for governmental regulators, to take into consideration how providers of audit service perceive the quality of what they do. The purpose of this section is to shed the light on the perceptions of audit profession in Libya concerning how auditors perceive the quality of the service provided. Further, this section analyses the differences between the perceptions of the staff of Audit Company and the staff oil firm.

The questionnaire survey findings, revealed that $68.5 \%$ of oil company respondents and $56.3 \%$ of audit firm participants either strongly agree or agree with the item: The current level of audit quality in Libya is insufficient. Whilst there was a disparity between the two groups, more than half of both populations were, nonetheless, of the opinion that there needed to be improvements in audit quality. $96 \%$ these interviewees thought the current level of audit quality was insufficient, the interviewees referred to reasons such as this could be due to the perceived lack of auditors' professionalism in Libya, since $51.9 \%$ and $43.8 \%$ of respondents of oil companies and audit firms either strongly agree or agree with the item that the lack of the professionalism of auditors in Libya causes the low level of audit quality. Another interesting finding is that just over half of the respondents $(62.2 \%$ and $56.9 \%)$ either strongly agree or agree with the item that most audit firms in Libya have little idea about new services, such as assurance services and internet reporting.

Additionally, the current rules and regulations are perceived to be weak, thereby providing poor audit quality. In this respect, $59 \%$ and $61.3 \%$ of oil company and audit firm respondents respectively believed these to be insufficiently comprehensive, and that the LAAA is not performing its role either in enhancing audit quality or in developing the accounting and auditing profession. On this matter, supervisor of audit in a local company affiliated to an Arab audit:

In my opinion, there are several reasons that have made audit quality in Libya insufficient, such as the lack of professionalism of auditors and the lack of strict penalties for violators of the rules of audit profession...In my view, I worked in the audit market for more than 31 years, I have never heard of any actions against 
undisciplined auditors.

This opinion was emphasized by a managing partner in a local audit company who noted:

It is believed that the current level of audit quality insufficient can be referred to reasons such as weakness in the current rules and regulations in terms of the absence of punitive fines and the accounting and the auditing education system in Libya are still insufficient to train auditors.

Likewise, a financial manager in one of the oil companies stated:

I think the lack of the role of the LAAA could be a cause of the level of audit quality being insufficient, because the LAAA has never done anything which could be identified as real enhancing audit quality and developing auditing profession.

In one of the Big Four, managing partner also confirmed the issue of staff qualification:

It is believed that the quality audit level is insufficient due to several reasons such as the absence of qualified and specialised staff and the shortage of professional and qualified accountants, and the absence of proper related laws that could support the LAAA in conducting its roles, and also most audit firms in Libya have no idea about new services, they are still audited using traditional methods.

The ineffectiveness of the LAAA was also observed by an auditor in local audit firm who added:

The LAAA should have adopted either American or International standards, and focused on how to improve the professionalism of accounting and auditing practitioners and on quality, from the beginning, ignoring this has contributed to the low level of audit quality.

All of the interviewees $(100 \%)$ criticised the LAAA for not classifying audit firms according to the number of staff, revenue, resources, and for not formulating any standard or principle of auditing or accounting, which has resulted in the lack of any theoretical basis for a Code of Ethics to which members of the profession must conform. Clearly, in the absence of such action on the part of the LAAA, it is entirely logical that the American standards and principles and have been followed.

This failure of the LAAA, despite being established more than three decades ago, to build any theoretical base for accounting as a profession in Libya, is questioned not only by the interviewees in this study, but has also been highlighted by many researchers who have confirmed the LAAA's failure to develop either accounting and auditing standards or a Code of Ethics to guide auditors' behaviour, and its adoption of a very limited role in the area of research, and professional control over accounting practices (Bakar \& Russell 2003; Kilani, 1988; Ahmed, 2004). This suggests that the LAAA has failed to regulate itself and to recognise its obligation towards the public interest. Furthermore, it has not achieved its objectives of furthering activities such as research, conferences, seminars, and generally promoting a programme of continuing training and education, which would include the publication of accounting research, all of which would enhance the status of the profession and accordingly of its members. All these factors suggest that the status of the Libyan accounting profession is below the required standard. The LAAA does not set uniform audit report requirements and no professional examination requirements. The main reasons for its limited role and, hence, impact, are as Mousa (2005) suggests, its small size and restricted authority.

One of the regulators who was interviewed commented on the LAAA's failure to achieve its objectives, saying: It is my view that the LAAA since establishment more than three decades ago is just the issue of new licences and taking fees from the members for their membership. Furthermore, it has not achieved its objectives of furthering activities such as activities such as seminars and conferences, research, and continuing education.

And an accounts manager in an oil company also referred to the length of time that the LAAA had had to organise the profession, saying: In my view, the level of audit quality is insufficient, even though the LAAA has been in existence now for almost three decade; some of the reasons identified include the lack of supervision by the LAAA, the lack of strong penalties and the lack of sufficient rules and regulations.

This view was echoed by a managing partner in local company affiliated to an Arab audit company who pointed out: I don't think that the LAAA is playing an essential key role in enhancing audit quality and developing audit profession. This is because they are not classifying audit firms according to the number of staff, revenue, resources, and number of clients, in order to help the clients decide which audit firms are most suitable for them, and this stresses again its failure to give attention to small (local) audit firms.

Its failure to impose a strict regulatory framework was also commented on by an accounts manager who added: In my view the LAAA haven't imposed strict conditions on each applicant for a license to practice the profession which reflects the lack of the professionalism of auditors and low audit quality. 
In conclusion, it can be said that the profession itself perceives its own work to be of inadequate quality, and that those involved attribute this lack of quality to be the result of an ineffective regulatory framework, which should be provided by the LAAA. Because of the inaction of the LAAA there is no remarkable development of the profession. Thus auditors are left to their own devices with no threat of disciplinary action for poor performance.

\subsection{Summary}

In this study, the results of the questionnaire and the interviews revealed that the vast majority of participants disagreed with the idea that the LAAA plays an essential key role in enhancing audit quality and developing audit profession. Respondents were, in fact, dissatisfied with the current level of audit quality in Libya, and indicated a preference for the Big Four other than local audit companies because they are perceived to offer a better quality product. Indeed, because most oil companies prefer to engage audit firms that are affiliated to a foreign audit company, as emphasized by the majority of participants, these firms tend to dominate the Libyan audit market. Again, the majority of participants involved in this study were of the opinion that most audit firms in Libya are unfamiliar with new audit services, such as assurance services and internet reporting. This situation may arise either because the majority of audit clients in Libya are still audited using traditional ways of auditing services, or because oil companies that provided the sample for the study, do not themselves have any idea about such new services. This particular finding is consistent with the literature (see Mautz and Sharaf, 1961).

In respect of the interviewees, they felt it was as a huge shortcoming of the LAAA that it had not undertaken any classification of audit firms in Libya according to the number of staff, revenue, and resources, and that it had not provided the profession with any standards or principles of auditing or accounting, nor formulated a Code of Ethics as is present in most other professions as a soft regulatory mechanism.

In fact, it can be seen that the LAAA has actually failed to regulate itself since had this been done, it would have recognised its obligation to defend public interest. Furthermore, it has not achieved its objectives associated with the promotion of activities such as research, conferences, academic publications, and seminars. This failure, together with the lack of any programme of continuing training and education has resulted in the absence of any effort to enhance the status of the profession and accordingly, the individual status of its members. Moreover, the LAAA specifies no uniform audit report requirements, or professional examination requirements. Clearly, it can be concluded that the Libyan accounting profession is extremely weak when evaluated against that in other countries, especially in the advanced nations.

Hence, the interviewees' opinions were not favourable about the current level of audit quality. The lack of the professionalism among auditors in Libya, the weaknesses in the current regulatory framework, the ineffectiveness of the LAAA, the ignorance of audit firms in Libya in respect of new services, and the inability of Libya's education system to produce graduates of a good enough calibre, all combine to cause the low level of audit quality that the profession itself wishes to improve.

\section{Overall Conclusion}

The study has been exploratory in nature, and has considered the Libyan audit environment using the oil sector as the unit of analysis. Given the international nature of Libya's oil industry, it is believed that the findings of the study provide an important directions for the new Libyan government in regulating the audit profession and thereby promoting Libya to foreign investors, not just in the oil sector but in other areas of the economy. It is believed, therefore, that the study has made several contributions in terms of both the literature, and the future development of a nation.

\section{References}

Ahmad, N., \& Gao, S. (2004). Changes, Problems and Challenges of Accounting Education in Libya. Accounting Education: International Journal, 13(3), 365-390. http://dx.doi.org/10.1080/0963928042000273825

American Institute of Certified Public Accountants (AICPA). (1991). Code of Professional Conduct. New York: Author.

Auditing Practices Board (APB). (2004). Integrity, Objectivity, and Independence. APB Ethical Standard 1. London, UK: APB.

Bakar, M., \& Russell, A. (2003). The Development of Accounting Education and Practice in Libya. In R. S. O. Wallace, J. M. Samuels, R. J. Briston \& S. M. Saudagaran (Eds.), Research in Accounting in Emerging Economies. Oxford, Elsevier Science.

Balsam, S., Krishnan, J., \& Yang, J. S. (2003). Auditor Industry Specialisation and Earnings Quality. Auditing: A

Journal of Practice \& Theory, 22(2), 71-97. http://dx.doi.org/10.2308/aud.2003.22.2.71 
Catanach, A. H., \& Walker, P. (1999). The International Debate Over Mandatory Auditor Rotation: A Conceptual Research Framework. Journal of International Accounting, Auditing, and Taxation, 8(1), 43-66. http://dx.doi.org/10.1016/S1061-9518(99)00004-X

Central Bank of Libya. (2006). Economic Bulletin, Annual Report. Research and Statistics Department.

DeAngelo, L. E. (1981). Auditor Size and Audit Quality. Journal of Accounting and Economics, 3, 183-199. http://dx.doi.org/10.1016/0165-4101(81)90002-1

Dopuch, N., \& Simunic, D. (1980). The Nature of Competition in the Auditing Profession: A Descriptive and Normative View. In J. Buckley, \& F. Weston, (Eds.), Regulation and the Accounting Profession.

Hasan, S. A. (2000). Indications to Audit Quality. Journal of Economic and Business, 35(2), 203.

Hofstede, G. (1984). Culture's Consequences: International Differences in work-Related Values. Beverly Hills: Sage Publications.

Hogan, C. E., \& Jeter, D. C. (1999). Industry Specialisation by Auditors. Auditing: A Journal of Practice \& Theory, 18, 1-17. http://dx.doi.org/10.2308/aud.1999.18.1.1

Humphrey, C. (1997). Debating Audit Expectations (2nd ed.). London: Paul Chapman.

International Auditing and Assurance Standards Board (IAASB). (2004a). Objective and General Principles Governing an Audit of Financial Statements, ISA 200. New York: IFAC.

International Auditing and Assurance Standards Board (IAASB). (2004b). The Auditor's Responsibility to Consider Fraud in an Audit of Financial Statements, ISA 240 (Revised). New York: IFAC.

International Federation of Accountants (IFAC). (2005). Code of Ethics for Professional Accountants. New York, NY: 1FAC.

Jensen, M. C., \& Meckling, W. H. (1976). Theory of the Finn: Managerial Behaviour, Agency Costs and Ownership Structure. Journal of Financial Economics, 3(4), 305-360. http://dx.doi.org/10.1016/0304-405X(76)90026-X

Kilani, K. A. (1988). The Evaluation and Status of Accounting in Libya. Unpublished PhD Thesis, University of Hull, UK.

Lys, T., \& Watts, R. L. (1994). Lawsuits against Auditors. Journal of Accounting Research, 32, 65-93. http://dx.doi.org/10.2307/2491440

Mautz, R. K., \& Sharaf, H. A. (1961). The Philosophy of Auditing. American Accountants Association, USA.

Mousa, F, R. (2005). Developing a Model for Evaluating the Effectiveness of the Internal Audit Function in Libyan Organisation: Case Study with Special Reference to Oil Companies. Unpublished PhD thesis, the Manchester Metropolitan University, UK.

Owhoso, V. E., Messier, W. F., \& Lynch, J. G. Jr. (2002). Error Detection by Industry-specialised Teams During Sequential Audit Review. Journal of Accounting Research, 40, 883-900.

Porter, B., Simon, J., \& Hatherly, D. (2003). Principles of External Auditing (2nd ed.). England: John Wiley \& Sons.

Remenyi, D., Williams, B., Money, A., \& Swartz, E. (2002). Doing Research in Business and Management. London, SAGE Publications.

Saleh, M. M. (2001). Accounting Information Disclosure and Accountability: Case from Libya. Unpublished $\mathrm{PhD}$ thesis, Sheffield Hallam University.

Saunders, M., Lewis, P., \& Thornhill, A. (2007). Research Methods for Business Students (4th ed.). Prentice Hall.

Selway, M. (2000). Over the Hump. Accountancy, 125(1280), 68-69.

Shareia, B. (1994). Responsibility of the External Auditor in Libya, An Empirical Study Unpublished Masters thesis. University of Garyounis, Libya.

Solomon, I., Shields, M. D., \& Whittington, O. R. (1999). What Do Industry Specialist Auditors Know? Journal of Accounting Research, 37, 191-208. http://dx.doi.org/10.2307/2491403

World Markets Research Centre. (2002). Country Analysis and Forecast Country Report Libya. London: WMRC PLC Company. 


\section{Copyrights}

Copyright for this article is retained by the author(s), with first publication rights granted to the journal.

This is an open-access article distributed under the terms and conditions of the Creative Commons Attribution license (http://creativecommons.org/licenses/by/3.0/). 